\title{
Ampulla of Vater Pancreatobiliary Type Adenocarcinoma
}

National Cancer Institute

\section{Source}

National Cancer Institute. Ampulla of Vater Pancreatobiliary Type Adenocarcinoma. NCI

Thesaurus. Code $C 95963$.

An invasive adenocarcinoma that arises from the ampulla of Vater. It is characterized by the presence of malignant cells that resemble the malignant cells of the pancreatic ductal or extrahepatic bile duct carcinomas. 